\title{
SCREENING OF MUNGBEAN ACCESSIONS UNDER SALINITY STRESS
}

\author{
Moushree Sarkar and Sabyasachi Kundagrami*
}

Department of Genetics and Plant Breeding, Institute of Agricultural Science, University of Calcutta, 51/2, Hazra Road, Kolkata 700019, West Bengal, India

Keywords: Agro-morphological parameters, Correlation, Mungbean, RTDM, Salinity stress

\begin{abstract}
Experiments were conducted to identify suitable agro-morphological indicators of salinity tolerance and to classify fifty mungbean accessions into different salt tolerant groups by screening under different $\mathrm{NaCl}$ solution in pot culture in green house condition for two growing seasons. Results reveled that the early growth phase of mungbean is highly affected due to salinity and the interrelationship between salinity and accessions was also statistically significant for yield parameters under different levels of salinity stress. Salt tolerant accessions were less affected at high salinity and could be produced better total dry matter as compared to others. On the basis of relative total dry matter (RTDM\%), accessions were categorized as highly tolerant, moderately susceptible and highly susceptible. G4 was found to be the best tolerant line after considering both the seasons and all the tested parameters. Correlation study suggested that germination was least affected while seedling length, pod and seed yield severely fractured due to salinity. These desirable parameters may take part in future breeding programme as salinity indicators and also by getting introduced into the susceptible lines, whereas, the tolerant accessions can be introduced as tolerant checks.
\end{abstract}

\section{Introduction}

Mungbean (Vigna radiata L. Wilczek) is a major edible legume in Asia, Southern Europe and Southern USA. India stands first in case of production and consumption of mungbean and accounts for about $65 \%$ of the cultivable land and $54 \%$ of the world production of this crop (Sehrawat et al. 2013). It can fix atmospheric nitrogen $(58-109 \mathrm{~kg} / \mathrm{ha}$ ) in symbiotic association with Rhizobium. The average yield of mungbean is very low in India mainly due to low inherent yield potential and susceptibility to biotic and abiotic stresses (Sehrawat et al. 2013). Among the different abiotic stress, salt stress is a chronic threat to mungbean yields, especially in countries with irrigated agriculture.

Physiologically, high salinity causes decrease in growth, reduction in water uptake resulting in osmotic imbalance leading to ion injury and ultimately decrease yield with poor seed quality. Now-a-days a globally more than 45 million ha of cultivated land is affected by salinity each year (Munns and Tester 2008). Salinity stress in mungbean is associated with a decline in seed germination, seedling vigor and photosynthetic activity, all of which lead to decrease in yield (Abdul Wahid and Ejaz 2004). As low as $50 \mathrm{mM} \mathrm{NaCl}$ can cause yield loss in mungbean as reported by Abd-Alla et al. (1998). Cultivation of mungbean is often done on irrigated soils where accumulated salt decreases the osmotic potential of the soil, leading to water stress, imparting nutrient imbalances which cause metabolic damage and cell death in the plants (Hasanuzzaman et al. 2013).

Therefore, screening of salt response of existing popular germplasms of mungbean and proper management practice to alleviate the adverse effect of soil salinity is urgently needed. Attempts have also been made to evaluate mungbean germplasm in natural saline areas (Chauban 1997) as well as by cell culture technique, physiological and biochemical characteristics (Raza et al. 2002).

*Author for correspondence: <skundagrami@gmail.com>. 
Keeping in view the importance of salinity stress, selection of salinity tolerant mungbean genotypes are essential to increase mungbean production in the country. Thus in this study efforts have been undertaken in screening of mungbean genotypes for salinity stress on the basis of agromorphological indicators.

\section{Materials and Methods}

A total number of fifty high productive extra short duration accessions of mungbean consisting of 22 germplasms (G1-G22), 20 mutant lines (CUM1-CUM20) and 8 segregating lines (CUH1-CUH8) were collected from the germplasm collection at Department of Genetics and Plant Breeding, University of Calcutta (Sarkar and Kundagrami 2018). Three different salinity levels $(150,200$ and $300 \mathrm{mM})$ were used in the form of $\mathrm{NaCl}$ solution for imposing the salinity stress. The control was without salts $(0 \mathrm{mM})$.

Experiment was conducted under semi-controlled environment inside greenhouse $\left(25^{\circ} \mathrm{C}\right.$ Day/ $20^{\circ} \mathrm{C}$ Night, $65 \%$ relative humidity, $16 \mathrm{hrs} / 8 \mathrm{hrs}$ photoperiod, with light intensity, maintained at $750 \mu \mathrm{mol} \mathrm{m}{ }^{-2} \mathrm{~S}^{-1}$ ) during two grwoing season of 2018-2019. The $1^{\text {st }}$ sowing was on 14.5 .2018 and $2^{\text {nd }}$ sowing was on 18.3.2019.

Viable and surface sterilized (1.0\% NaOCl solution) seeds of all the mungbean accessions were sown in pots containing sandy loam soil in randomized block design (RBD) with three replications per treatment. At the time of sowing saline water was used as irrigation practice for all the treated pots. Control pot was irrigated with normal water. Per cent germination was calculated at 4DAS. After that, until 15DAS irrigation practice was maintained with normal water for treated as well as control pots. After this period, salinity stress was imposed by fertigation technique following the protocol mentioned by Manasa et al. (2017). Above mentioned three levels of stress was given by adding $500 \mathrm{ml}$ of each salt solution for stressed plants based on the field capacity of the soil to avoid leaching. Likewise, stress was imposed thrice at 15, 30 and 40DAS. Normal irrigation was practiced in intervals. At 15DAS seedling length and Relative total dry matter percent were calculated and at the time of maturity different agro-morphological parameters viz., plant height $(\mathrm{cm})$, number of branches and number of pods per plant and seed yield/plant $(\mathrm{g})$ were taken on five randomly selected plants/ line/treatment. Data on different salinity parameters were recorded as follows:

$\%$ Reduction of parameters $=\frac{\text { Control }- \text { Treatment }}{\text { Control }} \times 100$

$\%$ Relative total dry matter $(\mathrm{RTDM})=\frac{\text { Dry wt. under salinity stress }}{\text { Dry wt. under non saline condition }} \times 100$

Scoring of salinity was done using 0 - 9 scale based on RTDM\% (Ashraf and Waheed 1990). All the statistical analysis were done using IBM-SPSS 16.0 and SPAR 2.0 statistical software.

\section{Results and Discussion}

Accessions did not show significant difference under control condition $(0 \mathrm{mM} \mathrm{NaCl})$ for all the tested parameters during both the growing seasons. But accessions under salinity stress reported considerable variation for all the tested parameters in both the seasons (Table 1).

Seed germination per cent was reduced under salinity stress in both the seasons. The pooled value of both the seasons for per cent reduction in seed germination ranged from $0-20 \%$ in 150 $\mathrm{mM}, 10-30 \%$ in $200 \mathrm{mM}$ and $30-50 \%$ in $300 \mathrm{mM}$ over control $(0 \mathrm{mM})$. Thus, higher level of 


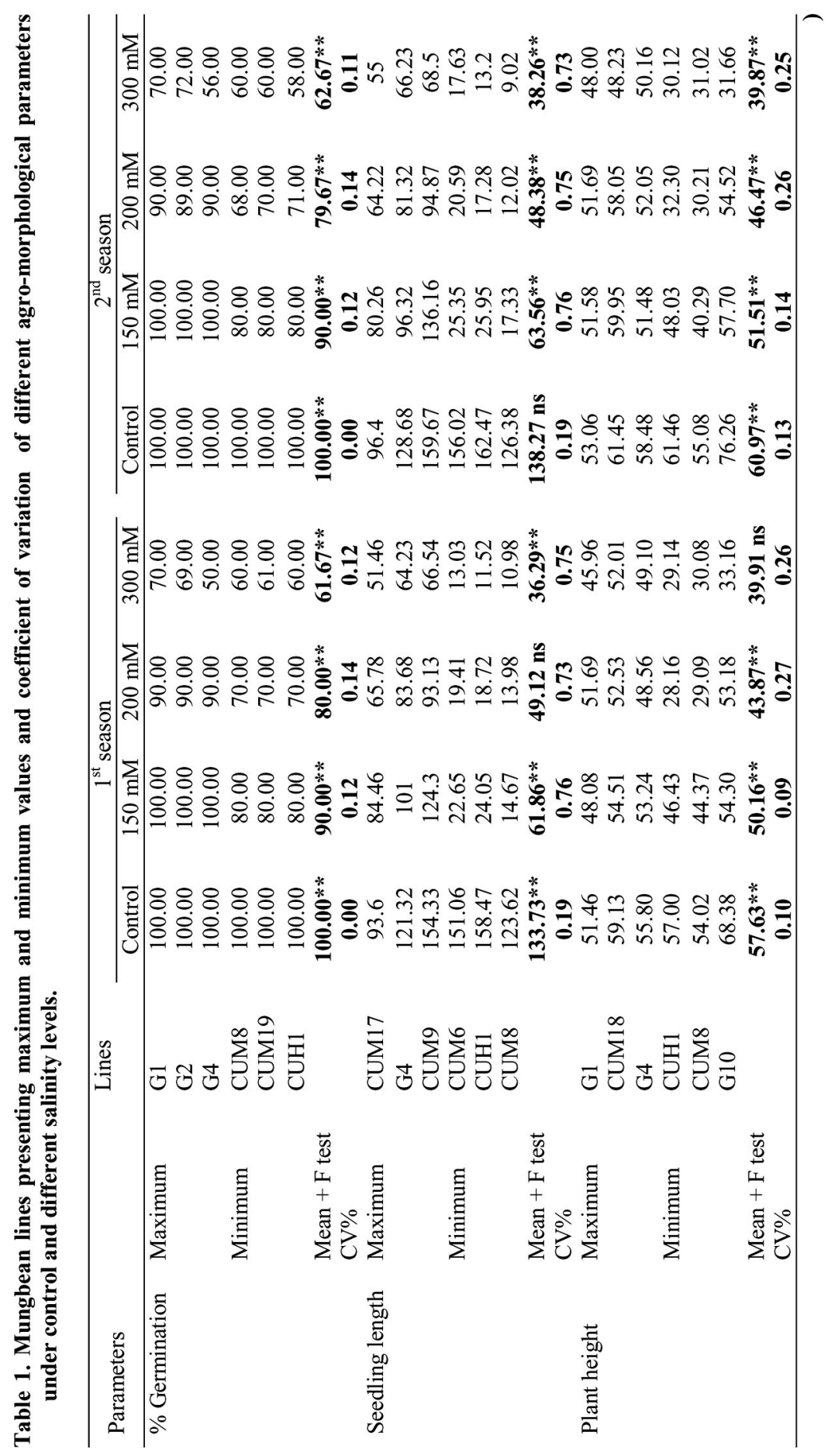




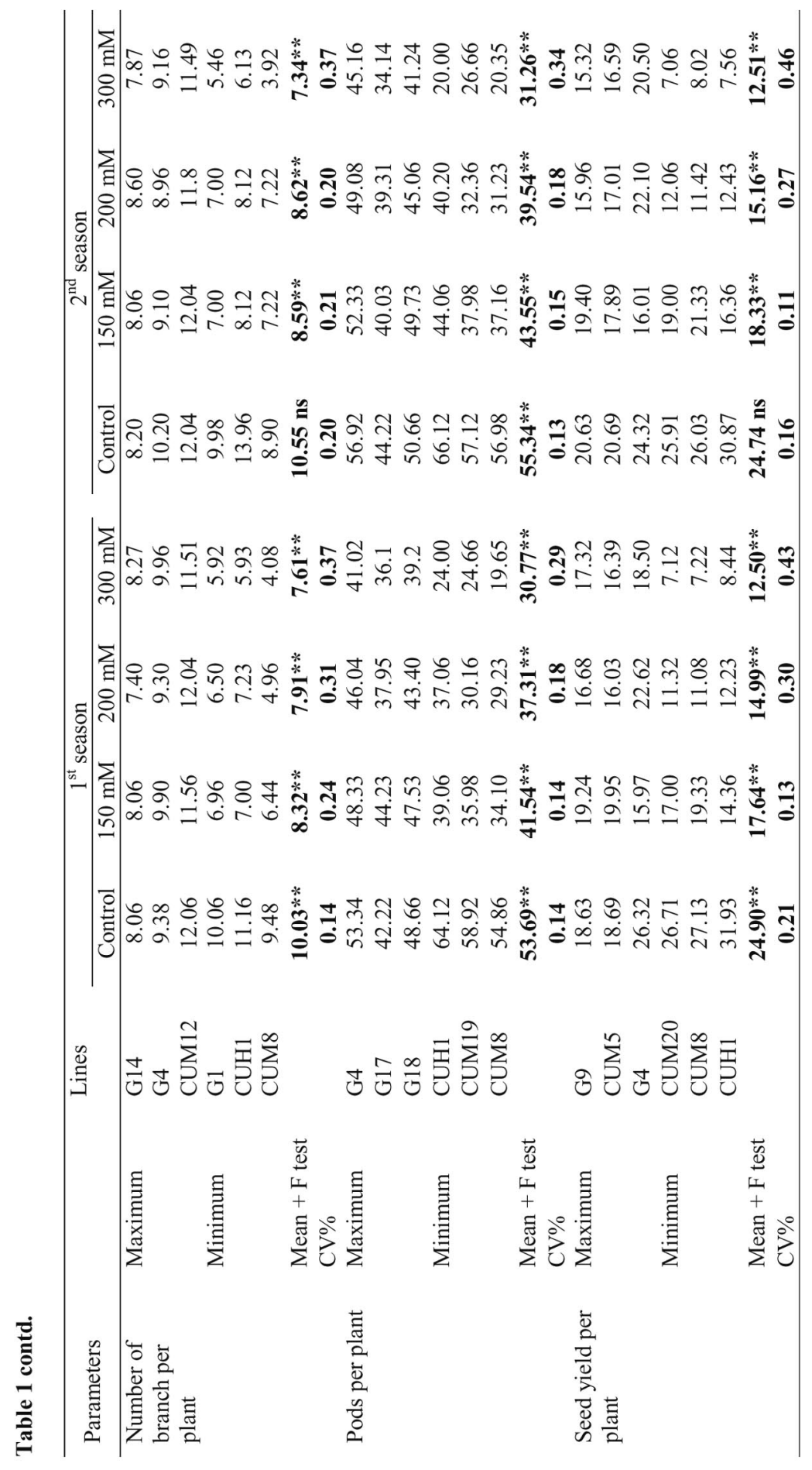


salinity significantly reduced the germination per cent. That may happend due to increased amount of sodium/chloride ions in soil which ultimately reduced the adequate water uptake by creating an outside osmotic potential, ion toxicity (Sehrawat et al. 2013).

The growth of seedling was affected under salinity stress due to reduction in root and shoot lengths with considerable genotypic variations. Reduction on the basis of pooled value of both the seasons, seedling length at 150,200 and $300 \mathrm{mM}$ salinity stress was found to range from 13 - 87, 32 - 90 and $44-92 \%$, respectively. Highest reduction over control based on pooled value of seedling length was reported in CUM17 (13\% in $150 \mathrm{mM}, 32 \%$ in $200 \mathrm{mM}$ and $44 \%$ in $300 \mathrm{mM}$ ) followed by G4 ( $21 \%$ in $150 \mathrm{mM}, 34 \%$ in $200 \mathrm{mM}$ and $48 \%$ in $300 \mathrm{mM}$ ) (Table 1). These findings are in line with the previous reports of Mahdavi and Modarres Sanavy (2007), Sehrawat et al. (2013).

All the agro-morphological parameters showed decreased performance and a significant variation among the accessions with elevated salinity level during both the seasons (Table 1). At control condition pooled values of plant height and number of branch per plant varied from 52.26 $72.32 \mathrm{~cm}$ and 8.13 to 12.56 , respectively, whereas, $42.33-57.23 \mathrm{~cm}$ and $6.83-11.8$, respectively at $150 \mathrm{mM}$ salinity stress, $29.65-55.29 \mathrm{~cm}$ and $4.96-11.92$, respectively at $200 \mathrm{mM}$ salinity stress and $29.63-50.12 \mathrm{~cm}$ and $4.00-11.50$, respectively at $300 \mathrm{mM}$ salinity stress. At $300 \mathrm{mM}$ salinity stress, the maximum reduction in plant height and branch number was recorded in G10 followed by CUM8 and CUM8 followed by CUH1 respectively. Pooled value over both the season registered a significant reduction among the accessions in case of pod number. Depending on the average value of pods per plant CUM8 followed by CUM19 recorded highest reduction over control at 300mM salinity stress and G18 followed by G17 and G4 recorded lowest reduction over control at $300 \mathrm{mM}$ salt stress. At control condition seed yield per plant varied from $18.63-31.93 \mathrm{~g}$ whereas, $14.36-19.95 \mathrm{~g}$ at $150 \mathrm{mM}, 11.32-22.62 \mathrm{~g}$ at $200 \mathrm{mM}$ and $7.12-18.50 \mathrm{~g}$ at $300 \mathrm{mM}$ salinity stress during $1^{\text {st }}$ season. On the other hand seed yield plant ranged from $24.32-30.87 \mathrm{~g}$ at control, $16.01-19.40 \mathrm{~g}$ at $150 \mathrm{mM}, 11.42-22.10 \mathrm{~g}$ at $200 \mathrm{mM}$ and $7.06-20.50 \mathrm{~g}$ at $300 \mathrm{mM}$ salinity stress during $2^{\text {nd }}$ season. The highest reduction of pooled value of seed yield per plant over control was recorded as $75 \%$ in CUH1 followed by $71 \%$ in CUM8 at $300 \mathrm{mM}$ saline stress. The reduction in different yield parameters with increase in salinity stress in mungbean is also reported by Mahdavi and Modarres Sanavy (2007), Sehrawat et al. (2013) and others. The variances between germplasms might be due to some genetic factors as well as heredity dissimilarities (Win et al. 2011). Present study suggested that the lower salinity treatment $(150 \mathrm{mM})$ reduced these parameters to a slighter degree than moderate $(200 \mathrm{mM})$ and high $(300 \mathrm{mM})$ salinity treatments.

At $300 \mathrm{mM}$ salinity stress the average RTDM ranged from $30-95 \%$. The highest RTDM was recorded in G4 followed by G9 (93\%) and lowest in CUH1 (34\%). Earlier findings of different researchers reported that salt tolerant accessions was found to be less affected at higher salinity stress and could produce higher TDM as compared to others (Ashraf and Waheed 1990, Uddin and Hossain 2018). Therefore, based on the RTDM the tested accessions were classified into ten groups using 0-9 scale (Fig. 1A) and further categorized as tolerant (T), moderately susceptible (MS) and highly susceptible lines (HS) (Ashraf and Waheed 1990). Results reveled that 0, 1 and 9 scales had no genotypes. The highest number of accessions was found in scale number 5 during both the seasons. Based on this categorization Fig. 1B further revealed that tolerant (T), moderately susceptible (MS) and highly susceptible categories included 11, 31 and 8 accessions, respectively during $1^{\text {st }}$ season and 13,30 and 7 accessions, respectively during $2^{\text {nd }}$ season. Therefore, based on the pooled value of scoring of salinity using 0 - 9 scale the accessions namely CUM5, G9, G4, G14, G5, G13, G6, G15, G3, G2, G1 were catagorized as tolerant accessions (Table 2). Interestingly, by cumulating the result of all the tested parameters, G4 recorded lower reduction and CUM8 along with CUH1 recorded higher reduction under salinity stress over 
control than other accessions. Therefore, these accessions could be a useful stock for further breeding programmes aims to develop salinity tolerant mungbean lines.

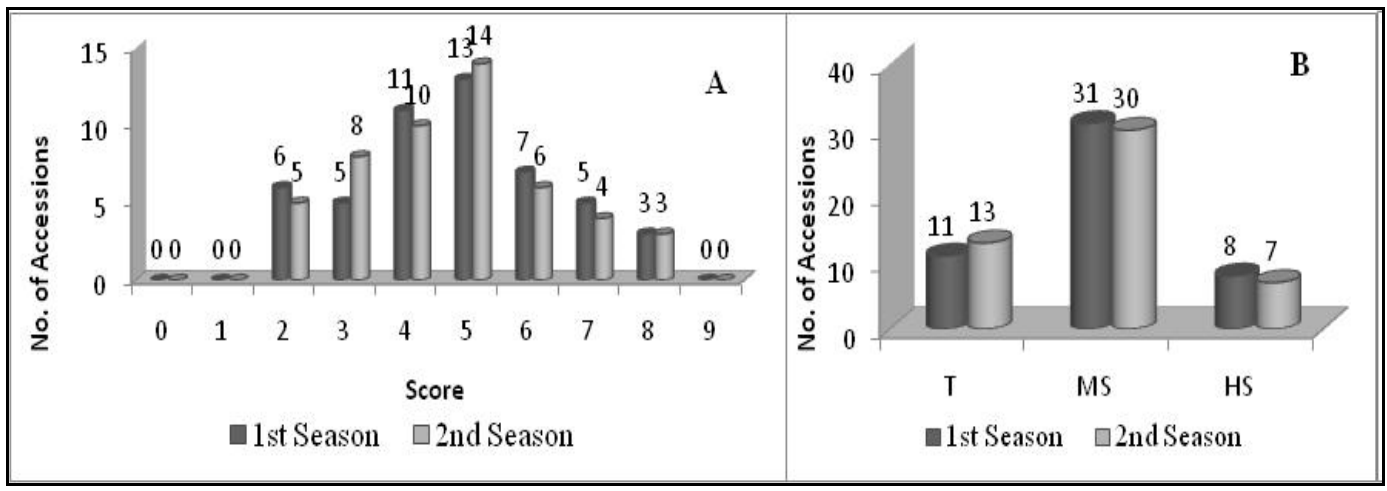

Fig. 1. Frequency distribution of 50 mungbean accessions in salinity tolerance scale based on RTDM (A) and on relative performance and salinity tolerant scale (B) during both the seasons.

Table 2. Grouping of $\mathbf{5 0}$ mungbean lines on the basis of reduction in seed yield parameters under $\mathbf{3 0 0}$ mM salinity treatment.

\begin{tabular}{llcl}
\hline & Salt response & Score & \multicolumn{1}{c}{ Name of accessions } \\
\hline I & Tolerant & $0-3$ & CUM5, G9, G4, G14, G5, G13, G6, G15, G3, G2, G1 \\
II & $\begin{array}{l}\text { Moderately } \\
\text { susceptible }\end{array}$ & $4-6$ & G7, G21, G8, G12, G10, CUM18, G22, G17, G16, CUH6, G20, G19, \\
& & & $\begin{array}{l}\text { CUM1, CUM15, CUH7, CUM19, CUM4, CUM7, CUM11, CUM6, } \\
\text { G11, CUH5, CUM3, CUM9, CUM12, CUM2, CUH2, CUH8, CUM13, }\end{array}$ \\
& & & $\begin{array}{l}\text { CUM17. } \\
\text { CUH4, CUM10, CUH3, CUM8, CUM14, CUM20, CUH1, CUM16 }\end{array}$ \\
III & $\begin{array}{l}\text { Highly } \\
\text { susceptible }\end{array}$ & $7-9$ & CUn \\
\end{tabular}

The relationships among different agro-morphological parameters and salt tolerance at 3 different salinity stresses are represented in terms of correlation analysis. Correlation study reported a significant positive relation between seed yield with per cent germination, seedling length, plant height, number of branch per plant and number of pods per plant at lower salinity stresses $(150$ and $200 \mathrm{mM})$, but with the increment of salinity no such significant correlation was found (Table 3). Highly positive correlation between number of pods per plant with number of branch per plant, regardless of salinity, have also been observed. But plant height did not show any significant relation with tolerance index, which indicates that this parameter may not be a good indicator of salinity tolerance. However number of branch per plant registered nonsignificant relation with tolerance index at lower salinity $(150 \mathrm{mM}$ and $200 \mathrm{mM})$ but with increase in salinity level, significant negative correlation $(-70)$ was observed (Table 3). Negative correlation suggests that with the increment of the branch number there might be a gradual decrement of the tolerance index (Standard evaluation score) denoting more tolerance of accessions (Ali et al. 2014). This outcome might be an efficient tool to find the better indicators of salinity tolerance in comparison to other agro-morphological parameters.

Salinity tolerance scale based on RTDM value was found to be the most efficient tool in classifying the large number of accessions in different categories. Based on the pot screening the 
accessions viz., CUM5, G9, G4, G14, G5, G13, G6, G15, G3, G2, G1 may be considered as salt tolerant lines.

Table 3. Pooled correlation matrix among the agro-morphological parameters at different salinity stress.

\begin{tabular}{|c|c|c|c|c|c|c|c|}
\hline & $\begin{array}{l}\text { Doses } \\
(\mathrm{mM})\end{array}$ & $\mathrm{G} \%$ & $\begin{array}{l}\text { Seedling } \\
\text { length } \\
(\mathrm{cm})\end{array}$ & $\begin{array}{l}\text { Plant } \\
\text { height } \\
(\mathrm{cm})\end{array}$ & $\begin{array}{l}\text { Number } \\
\text { of branch } \\
\text { per plant }\end{array}$ & $\begin{array}{l}\text { Pod per } \\
\text { plant }\end{array}$ & $\begin{array}{l}\text { Seed yield } \\
\text { per plant }(\mathrm{g})\end{array}$ \\
\hline \multirow[t]{3}{*}{ Seedling length $(\mathrm{cm})$} & 150 & $0.08 * *$ & & & & & \\
\hline & 200 & $0.09 * *$ & & & & & \\
\hline & 300 & -0.08 & & & & & \\
\hline \multirow[t]{3}{*}{ Plant height $(\mathrm{cm})$} & 150 & -0.13 & 0.01 & & & & \\
\hline & 200 & 0.00 & -0.23 & & & & \\
\hline & 300 & 0.00 & -0.08 & & & & \\
\hline \multirow{3}{*}{$\begin{array}{l}\text { Number of branch } \\
\text { per plant }\end{array}$} & 150 & 0.14 & 0.32 & $-0.40^{*}$ & & & \\
\hline & 200 & $0.17 * *$ & 0.28 & $-0.52 *$ & & & \\
\hline & 300 & 0.20 & 0.17 & -0.21 & & & \\
\hline \multirow[t]{3}{*}{ Pod per plant } & 150 & 0.26 & $0.14 * *$ & -0.10 & $0.30 * *$ & & \\
\hline & 200 & 0.35 & 0.08 & -0.03 & $0.23 * *$ & & \\
\hline & 300 & 0.19 & 0.17 & -0.27 & $0.13 * *$ & & \\
\hline \multirow[t]{3}{*}{ Seed yield per plant } & 150 & $0.35^{* *}$ & $0.13 * *$ & $-0.22 * *$ & $0.37 * *$ & $0.39 * *$ & \\
\hline & 200 & $0.16^{*}$ & $0.05^{*}$ & $-0.16^{*}$ & $0.41 *$ & $0.10 *$ & \\
\hline & 300 & -0.16 & 0.37 & -0.11 & 0.08 & 0.04 & \\
\hline \multirow[t]{3}{*}{ Tolerance index } & 150 & $-0.06^{*}$ & $-0.08^{*}$ & -0.55 & -0.69 & $-0.65^{* *}$ & $-0.19 * *$ \\
\hline & 200 & -0.09 & $-0.16^{*}$ & -0.43 & 0.86 & $-0.58^{*}$ & $0.23 * *$ \\
\hline & 300 & -0.06 & -0.29 & -0.69 & $-0.70 *$ & $0.30^{*}$ & $0.29 * *$ \\
\hline
\end{tabular}

*,** Indicates $5 \%$ and $1 \%$ level of significance, respectively.

Correlation analysis concluded that plant breeders may give emphasis on number of pod per plant and seed yield per plant during selection of salt tolerant genotypes of mungbean under greenhouse condition. Moreover, these desirable parameters also take part in future breeding programme for saline soils by getting introduced into the susceptible lines.

\section{Acknowledgements}

Dr. Moushree Sarkar gratefully acknowledge the receipt of financial assistance in the form of a Research Associate (RA) Fellowship funded by the Council for Scientific and Industrial research, New Delhi, Government of India.

\section{References}

Abd-Alla MH, Vuong TD and Harper JE 1998. Genotypic differences in nitrogen fixation response to $\mathrm{NaCl}$ stress in intact and grafted soybean. Crop Sci. 38: 72. 
Abdul Wahid MH and Ejaz R 2004. Salt injury symptom, changes in nutrient and pigment composition and yield characteristics of mungbean.Int. J. Agri. Biol. 6: 1143-1152.

Ali N, Yeasmin L, Gantait S, Goswami R and Chakraborty S 2014. Screening of rice landraces for salinity tolerance at seedling stage through morphological and molecular markers. Physiol Mol Biol Plants. 20(4): 411-423.

Ashraf M and Waheed A 1990. Screening of local/exotic accessions of lentil (Lens culinaris Medic.) for salt tolerance at two growth stages. Plant and Soil 128: 167-176.

Chauban YS 1997. Screening of tolerance to salinity and water logging: Case study with pigeon pea and chickpea. In: Adaptation of chick pea to abiotic stresses. Proc. Consultants, ICRISAT 19-21.

Hasanuzzaman M, Nahar K and Fujita M 2013.Plant response to salt stress and role of exogenous protectants to mitigate salt-induced damages. In: Ecophysiology and Responses of Plants under Salt Stress.(Eds) Ahmad P, Azooz MM and Prasad MNV NewYork, NY: Springer, pp. 25-87.

Mahdavi B and ModarresSanavy SAM 2007. Germination and seedling growth in grasspea (Lathyrus sativus) cultivars under salinity conditions. Pak. J. Biol. Sci. 10: 273-279.

Manasa R, Raddy R, Bindumadhava H, Nair RM, Prasad TG and Shankar AG 2017. Screening mungbean (Vigna radiata $\mathrm{L}$.) lines for salinity tolerance using salinity induction response technique at seedling and physiological growth assay at whole plant level. Int. J. Plant, Animal Env. Sci. 7: 1-12.

Munns R and Tester M 2008. Mechanisms of salinity tolerance. Annu Rev. Plant Biol. 59: 651-681.

Raza HA, Muhammad N, Yasin AM and Ejaz R 2002. Morpho-chemical responses of gram (Cicer arietinum L.) to salinity and nitrogen. Asian J Plant Sci. 1(2): 171-173.

Sarkar M and Kundagrami S 2018. Selection of high yielding, extra short duration lines of mungbean derived through gamma radiation. Ind. J. Genet. Plant Breed. 78(2): 233-241

Sehrawat N, Bhat KV, Sairam RK and Jaiwal PK 2013. Screening of mungbean (Vigna radiata L. Wilczek) genotypes for salt tolerance. Int. J. Plant An. Env.Sci. 4: 36-43.

Uddin MS and Hossain KMW 2018. Screening of wheat genotypes against salinity at early vegetative stage in pot culture. Bangladesh J. Bot. 47(3): 381-387.

Win T, Oo AZ, Hirasawa T, Ookawa T and Yutaka H 2011.Genetic analysis of Myanmar Vigna species in responses to salt stress at the seedling stage. Afr.J. Biotechnol 10: 1615-16.

(Manuscript received on 5 October, 2019; revised on 28 August, 2020) 